\title{
RESEARCH
}

Open Access

\section{Isolation and characterization of betulinic acid from the stem bark of Feretia canthioides Hiern and its antimalarial potential}

\author{
Chiedozie O. Egbubine ${ }^{1 *}$, Modupe M. Adeyemi ${ }^{1}$ and James D. Habila ${ }^{2}$
}

\begin{abstract}
Background: Malaria is a parasitic disease that constitutes a major global health concern and the increasing resistance of Plasmodium falciparum strains to the commonly used antimalarial drugs has resulted in an increase in treatment failures (Zofou et al.,Malar Res Treat: 561342, 2011). Natural products isolated from plants used in traditional medicine have shown promising antimalarial actions in vitro, and these plants can serve as potential sources for new antimalarial drugs (Wright et al.,Phytother Res 8:149-152, 1994); hence, research into the use of medicinal plants for the treatment of malaria would provide viable options in the effective control of the disease by screening plant extracts for antimalarial activities and also isolating bioactive components from these extracts using TLC and column chromatographic techniques.

This research was focused on investigating the antimalarial potentials of the stem bark of Feretia canthioides Hiern used in the traditional treatment of malaria in Nigeria.
\end{abstract}

Results: In vitro antimalarial tests carried out on the plant extracts and isolated compound in this research revealed that the methanol extract displayed promising antimalarial activities with an inhibitory concentration $\left({ }^{(} C_{50}\right)$ value of $7.76 \mu \mathrm{g} / \mathrm{ml}$, the $\mathrm{n}$ hexane extract showed low activity with an $\mathrm{IC}_{50}$ value of $63.10 \mathrm{\mu g} / \mathrm{ml}$, while the ethyl acetate and dichloromethane extracts were found to be inactive with $\mathrm{IC}_{50}$ values above $100 \mathrm{\mu g} / \mathrm{ml}$. The isolated compound (betulinic acid) showed good antimalarial activity with an $\mathrm{IC}_{50}$ value of $12.60 \mathrm{\mu g} / \mathrm{ml}$ when compared with chloroquine phosphate which served as the positive control.

Detailed phytochemical screening of the plant extracts obtained after extraction of the plant material indicated that the methanolic extract of the stem bark of Feretia canthioides Hiern contained major plant secondary metabolites which include tannins, alkaloids, terpenoids, flavonoids, steroids, alkaloids, saponins and glycosides. Chromatographic techniques carried out on the methanolic extract of this plant led to the isolation of a pentacyclic triterpenoid compound identified to be betulinic acid which is been reported for the first time from the methanolic extract of the stem bark of this plant.

Conclusion: The inhibitory concentration values $\left({ } C_{50}\right)$ of the methanolic extract and isolated compound in this research prove that this plant can serve as an effective agent for the treatment of malaria. This research concluded that the stem bark of Feretia canthioides Hiern can be further investigated as a prospective antimalarial agent.

Keywords: Feretia canthioides Hiern, Betulinic acid, Antimalarial activity, TLC, 13C-NMR

\footnotetext{
* Correspondence: edozie.egbubine@gmail.com

'Department of Chemistry, Nigerian Defence Academy (NDA), Kaduna State,

Nigeria

Full list of author information is available at the end of the article
}

\section{Springer Open}

() The Author(s). 2020 Open Access This article is licensed under a Creative Commons Attribution 4.0 International License, which permits use, sharing, adaptation, distribution and reproduction in any medium or format, as long as you give appropriate credit to the original author(s) and the source, provide a link to the Creative Commons licence, and indicate if changes were made. The images or other third party material in this article are included in the article's Creative Commons licence, unless indicated otherwise in a credit line to the material. If material is not included in the article's Creative Commons licence and your intended use is not permitted by statutory regulation or exceeds the permitted use, you will need to obtain permission directly from the copyright holder. To view a copy of this licence, visit http://creativecommons.org/licenses/by/4.0/. 


\section{Background}

Medicinal plants have been utilized over a long period of time as remedies for treatment of various human diseases because of their active components of therapeutic value (Tanaka et al. 2002). These plants have been the basic source of traditional medicine for many years and have been vital in drug discovery and development. Malaria is one of the world's most dreaded disease caused by the parasite plasmodium falciparum (Zofou et al. 2011).

The rising spread of parasite resistance to antimalarial drugs in recent times has emerged as one of the greatest threats facing the control of the disease today with approximately 300 million cases and about one million deaths reported worldwide annually (Devi et al. 2014). These drug-resistant strains of malaria parasites have increased antimalarial drug research over a long period of time with more attention focused on natural products (Etkin 2003). A large number of people in Africa cannot afford the high costs needed for the treatment of malaria but can readily make use of traditional medicine for the treatment of malaria (Azas et al. 2002). Isolated compounds from plants used traditionally in medicine have the potential to serve as rich sources for the development of novel antimalarial drugs (Wright et al. 1994).

Feretia canthioides Hiern is a medicinal plant belonging to the Rubiaceae family of plants and is found on the anthills in the northern part of Nigeria and across the Congo basin to Sudan and East Africa. The plant is myremcophyllous, being often found on anthills (Dalziel et al. 2014) and the stem bark of the plant has been found useful in the treatment of fever usually associated with malaria amongst people living in the middle belt northern region of Nigeria. The plant is also referred to as KuruKuru in Hausa, Ikpochimalogo in Idoma and Tukulor in Senegal. Some of the medicinal uses of this plant are derived from the root which is usually taken as a decoction for treatment of gonorrhoea, syphillis, diabetes and leprosy (Dalziel et al. 2014). This research examined the antimalarial potentials of the stem bark of this plant to justify its claim in the traditional treatment of malaria by people living in rural areas in the northern middle belt region of Nigeria.

\section{Materials and methods}

\section{Collection of plant material and authentication}

The stem bark of Feretia canthioides Hiern was collected from Ayeje forest, Edumoga district in Okpokwu Local Government Area of Benue state, Nigeria, and was authenticated in the herbarium unit of the Department of Biological Sciences, Ahmadu Bello University, Zaria, Nigeria, with a specimen voucher number of 4499 .

The stem bark of this plant was collected between the periods of July 2017 to August 2017 in Benue state, Nigeria. The stem bark of the plant was air-dried and grounded into powder using a wooden mortar and pestle and sealed in an airtight polythene bag and stored at room temperature. The solvents used for extraction of the plant material were of analytical grade standards.

\section{Extraction of plant material Microwave-assisted extraction procedure}

The plant material $(1.4 \mathrm{~kg})$ was divided into 8 different portions each and placed in glass jar bottles. In total, $2.5 \mathrm{~L}$ of n-hexane was divided into the eight portions until it just covered the top of each of them and they were allowed to stand for $15 \mathrm{~min}$. The bottles were covered tightly and then irradiated in a microwave oven at $150 \mathrm{~W}$ at a temperature of $125^{\circ} \mathrm{C}$ and microwaved 4 times each at 3 min pulses removed and allowed to cool in between pulses. The microwaved plant extract was washed exhaustively using nhexane and filtered via a muslin cloth. This procedure was then repeated using dichloromethane, ethyl acetate and methanol respectively in order of increasing polarity. The extracts obtained were then concentrated using a rotary evaporator at a temperature of $40{ }^{\circ} \mathrm{C}$ and allowed to dry at room temperature (Dubey and Goel 2013).

\section{In vitro antimalarial assay Cultivation of malaria parasites}

An infected blood strain containing active Plasmodium falciparum parasites was obtained from Barau Dikko Specialist Hospital Kaduna. The infected blood was collected in a plastic sample bottle. The RPMI 1640 media supplemented with a $25 \mathrm{mM}$ HEPES buffer and glucose was the culture media used for parasite cultivation according to the method adopted by Trager and Jensen (2005).

\section{In vitro antimalarial activities}

The in vitro antimalarial activities in this research were performed using 96-well culture microplates, according to WHO methods, which are based on assessing the inhibition of schizont maturation (WHO 2000). The antimalarial activities of the n-hexane, ethyl acetate, dichloromethane and methanol extracts of Feretia canthioides Hiern including the isolated compound (betulinic acid) were determined by dilutions with the RPMI 1640 culture media to various concentrations of $100,80,60,40$ and $20 \mu \mathrm{g} / \mathrm{ml}$ respectively. The positive control used was chloroquine phosphate $(10 \mu \mathrm{g} / \mathrm{ml})$ which was added into each culture well. Fifty microlitres of parasitized blood was then added into each well and incubated under a $\mathrm{CO}_{2}$ incubator at $38^{\circ} \mathrm{C}$ for $24 \mathrm{~h}$. After incubation, contents of the wells were taken and stained for 30 min using a $2 \%$ Giemsa solution. The developed schizonts present in respective plate wells were then counted using an optical microscope (Olasehinde et al. 2014).

Determination of inhibitory concentration $\left(\mathrm{IC}_{50}\right)$ values The inhibitory concentration values of the plant extracts and isolated compound were determined from schizont 
Table 1 Inhibitory concentration $\left(\mathrm{IC}_{50}\right)$ values of plant extracts

\begin{tabular}{ll}
\hline Plant extracts & $I_{\mathbf{5 0}}$ values in $(\mu \mathrm{g} / \mathrm{ml})$ \\
\hline n-Hexane extract & 63.10 \\
Dichloromethane extract & 126.00 \\
Ethyl acetate extract & 147.91 \\
Methanol extract & 7.76 \\
\hline
\end{tabular}

growth inhibition graphs using Microsoft Excel, which is a plot of number of schizonts present in each plate well against the logarithm of concentrations (Mustofa et al. 2007). The optical microscopic determination of the number of mature schizonts present in respective plate wells at various concentrations was determined by viewing under an optical microscope. The inhibitory concentration $\left(\mathrm{IC}_{50}\right)$ values were then calculated from a linear equation given as $Y=m x+C$, after a trendline was added from a scatter plot diagram using Microsoft Excel, where $Y$ indicates the percentage inhibition denoted as 50, $x$ indicates concentrations, $m$ indicates a coefficient while $C$ is a constant (Mustofa et al. 2007). The values of $x$ were then calculated from the linear equation, and antilog of the values was taken to determine respective inhibitory concentration values.

\section{Isolation of compound}

The methanolic extract $(10 \mathrm{~g})$ was pre-adsorbed in a small quantity of ethyl acetate, mixed with a small quantity of silica gel and dried before been loaded unto a slurry packed silica gel column of dimension 75 by 3.5 $\mathrm{cm}$. The column was eluted continuously using only nhexane, followed by n-hexane: ethyl acetate mixtures as solvent systems used in eluting the column in the ratio $(80: 20)$. Fractions were collected in $10-\mathrm{ml}$ tubes at regular intervals. After a close inspection using TLC, fractions 25-31 having similar $R_{f}$ profiles were merged together. The combined fractions were then dried at

Table 2 Mature schizont count present in plate wells for isolated compound and positive control (chloroquine phosphate $10 \mu \mathrm{g} / \mathrm{ml}$ )

\begin{tabular}{llll}
\hline Isolated compound & $\begin{array}{l}\text { Concentration } \\
\text { and positive control }\end{array}$ & $\begin{array}{l}\text { Plate } \\
(\mu \mathrm{g} / \mathrm{ml})\end{array}$ & $\begin{array}{l}\text { Number of schizonts } \\
\text { wells }\end{array}$ \\
\hline present in respective wells
\end{tabular}

room temperature in a beaker and the formation of white needle-like crystals was observed. These combined fractions were spotted using TLC and a single brown spot was observed on the TLC plate after spraying with $10 \% \mathrm{H}_{2} \mathrm{SO}_{4}$ and heated in an oven at $112{ }^{\circ} \mathrm{C}$ for $3 \mathrm{~min}$. The isolated compound weighed $0.98 \mathrm{mg}$ and was then subjected to spectroscopic analysis.

\section{Results}

In vitro antimalarial activity of plant extracts represented as inhibitory concentration $\left(\mathrm{IC}_{50}\right)$ values

Table 1 below shows the inhibitory concentration values of the plant extracts which were determined by linear interpolation from schizont growth inhibition graphs; a plot of number of schizonts generated from each plate well against logarithm of concentrations using Microsoft Excel (Mustofa et al. 2007).

The inhibitory concentration $\left(\mathrm{IC}_{50}\right)$ values obtained from the in vitro antimalarial screening of the crude plant extracts in this study were classified according to their antimalarial potentials as described by Niharika et al. (2015). The n-hexane extract obtained from the stem bark of Feretia canthioides Hiern exhibited a marginal potency/ low activity with an $\mathrm{IC}_{50}$ value of $63.10 \mu \mathrm{g} / \mathrm{ml}$. The dichloromethane extract and ethyl acetate extract showed inactivity with $\mathrm{IC}_{50}$ values above $100 \mu \mathrm{g} / \mathrm{ml}$. The methanolic extract was found to be promisingly active with an $\mathrm{IC}_{50}$ value of $7.76 \mu \mathrm{g} / \mathrm{ml}$. This can be attributed to the fact that methanolic extracts contain most of the bioactive compounds from plant materials which are active on Plasmodia parasites (Niharika et al. 2015); hence, the isolated compound in this research was obtained from the methanolic extract of the plant owing to its promising in vitro antimalarial activity.

\section{Schizont count present in plate wells and inhibitory concentration values for isolated compound and positive control}

The optical microscopic readings of the number of mature schizonts present in each plate well for the isolated compound, and the positive control at various concentrations was determined by viewing under an optical microscope (Table 2). The $\mathrm{IC}_{50}$ values of the isolated compound and positive control (Table 3) was made from schizont growth inhibition graphs using Microsoft Excel; a plot of number of schizonts present in each plate well against the logarithm of concentrations (Mustofa et al.

Table 3 Inhibitory concentration $\left(\mathrm{IC}_{50}\right)$ values for isolated compound and positive control

\begin{tabular}{ll}
\hline solated compound and positive control & $\mid C_{50}$ values in $\mu \mathrm{g} / \mathrm{ml}$ \\
\hline Isolated compound & 12.60 \\
Positive control (chloroquine phosphate) & 40.00 \\
\hline
\end{tabular}




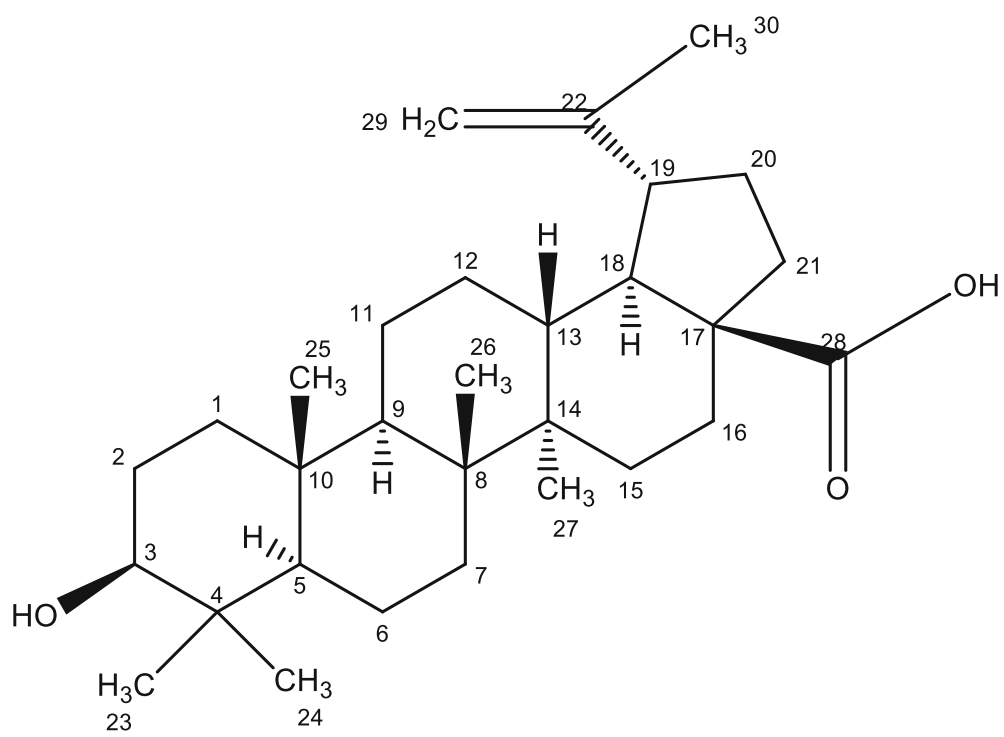

Fig. 1 Chemical structure of isolated compound $\left(\mathrm{C}_{30} \mathrm{H}_{48} \mathrm{O}_{3}\right)$

2007). The inhibitory concentration $\left(\mathrm{IC}_{50}\right)$ values of the isolated compound and positive control were determined to be $12.60 \mu \mathrm{g} / \mathrm{ml}$ and $40.00 \mu \mathrm{g} / \mathrm{ml}$ respectively.

\section{Spectroscopic analysis of isolated compound}

Figure 1 below shows the chemical structure of the isolated compound. A white crystalline compound was isolated and labelled DZ1. Figure 2 shows the IR spectral data of the isolated compound. The FTIR results of the isolated compound showed peaks at $2937 \mathrm{~cm}^{-1}$ and $2870 \mathrm{~cm}^{-1}$, which revealed the presence of $\mathrm{C}-\mathrm{H}$ stretching vibrations for methyl and methylene groups respectively. A prominent peak was observed at $1684 \mathrm{~cm}^{-1}$ indicating the presence of a $\mathrm{C}=\mathrm{O}$ bond and other bands appeared in the finger print region. Figure 3 shows the proton NMR results of the isolated compound. The ${ }^{1} \mathrm{H}$-NMR showed peaks at $1.81(2 \mathrm{H}), 1.53$ $(2 \mathrm{H}), 2.52(2 \mathrm{H})$, and singlets at 2.68 and 1.98 (1H each). A pair of singlets at -5.44 and $5.56(1 \mathrm{H}$ each) was due to the presence of vinyl protons at carbon position 29.

Table 4 above shows the ${ }^{13} \mathrm{C}$-NMR spectral data of the isolated compound in comparison with that obtained from literature. The ${ }^{13} \mathrm{C}$-NMR spectra of the compound showed a total of 30 carbon peaks, a common feature of a triterpenoid structure.

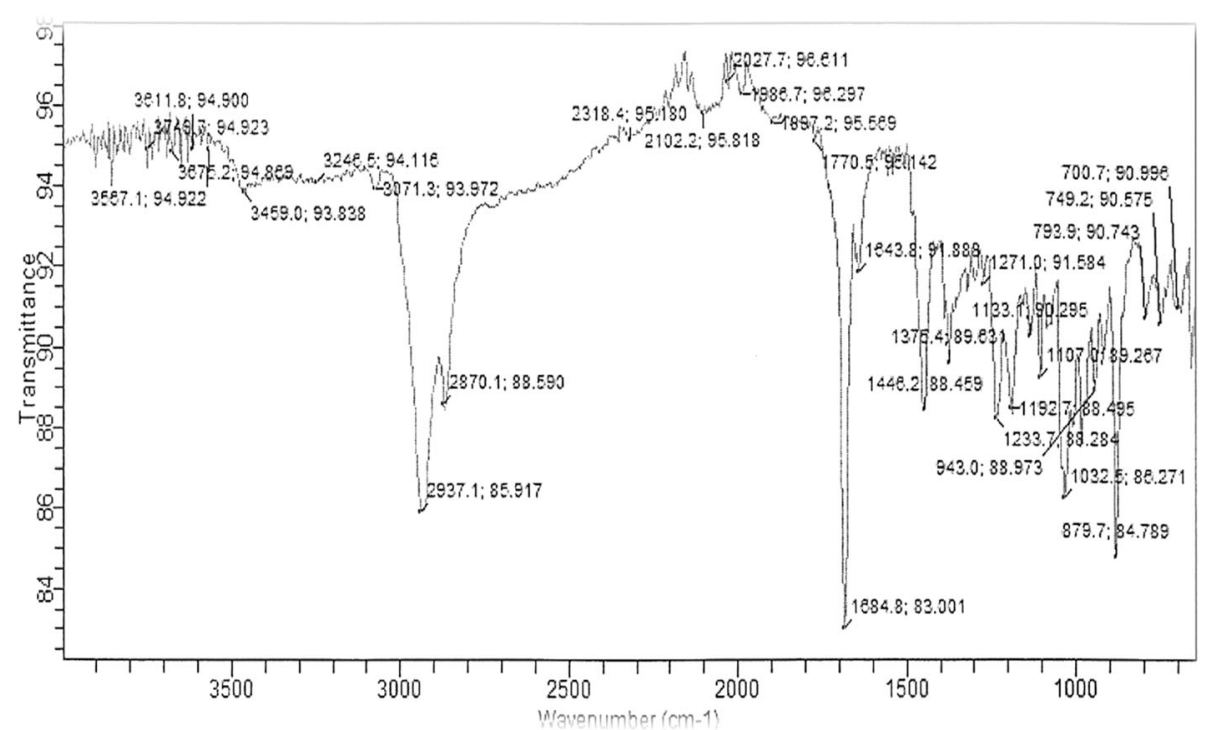

Fig. 2 IR Spectral data of isolated compound 


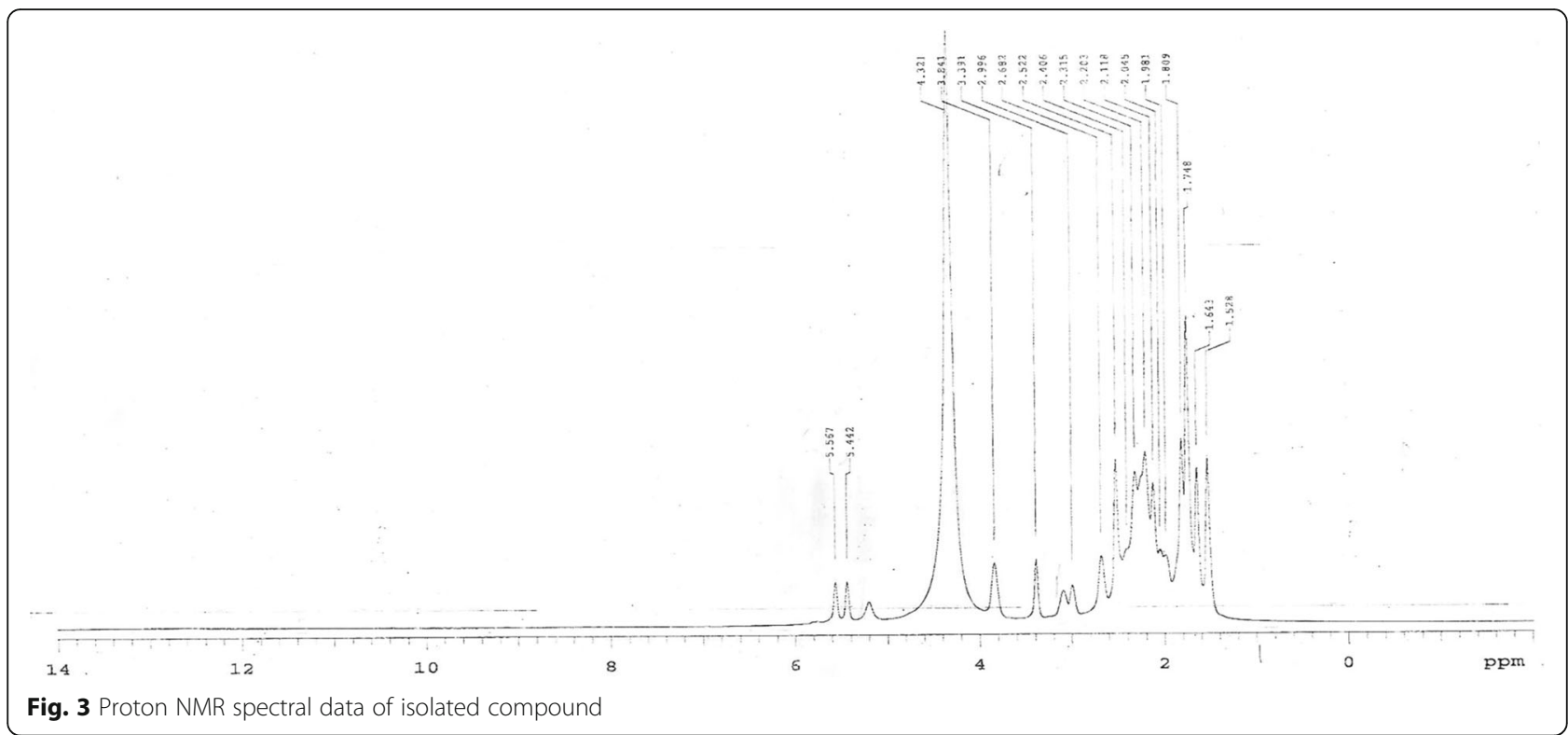

The ${ }^{13} \mathrm{C}$-NMR showed peaks at 150.52 (C-22), 177.49 (C-28), 109.82 (C-29), 14.58 (C-27), 77.04 (C-3), 55.63 (C-17), 55.12 (C-5), 50.15 (C-9), 48.73 (C-19), 42.19 (C-14), 46.84 (C-18), 39.43 (C-1), 38.71 (C-4), 39.97 (C-8), 31.93 (C-16), 34.13 (C-7), 36.93 (C-10), 25.29 (C-12), 15.94 (C-25), 37.78 (C-13), 19.14 (C-30), 15.94 (C-24), 29.43 (C-20), 18.17 (C-6), 16.09 (C-26), 28.30 (C-23), 38.71 (C-4), 27.36 (C-2), 30.33 (C-15) and $36.57(\mathrm{C}-21)$ giving a total of 30 carbon signals. The ${ }^{13} \mathrm{C}$-NMR of the isolated compound showed that there were 6 methyl carbons, 11 methylene carbons, 6 methine carbons, 1 carbonyl carbon and 6 quaternary carbons. All these put together account for 30 carbon signals characteristic of betulinic acid.

The ${ }^{13} \mathrm{C}$-NMR spectroscopic data of the isolated compound was compared with that obtained from literature (Mahato and Kundu 1993). The comprehensive literature survey and comparison with different spectral data identified the compound isolated in this research to be betulinic acid (Fig. 1).

\section{Discussion}

The assessment of the in vitro antimalarial activities of plant extracts and the isolated compound (betulinic acid) was done using the schizont maturation inhibition assay method (WHO 2000). In this method, a thin smear from each culture well was made on a glass slide and the parameter that was used for the assessment of in vitro antimalarial activities was the number of schizonts present in respective plate wells at various concentrations. This research also compared the antimalarial activities of the isolated compound with chloroquine phosphate which served as the positive control to ascertain the potential of this compound in the treatment of malaria.

The results of their respective $\mathrm{IC}_{50}$ values reveal that the isolated compound (betulinic acid) displayed good in vitro antimalarial activity with an $\mathrm{IC}_{50}$ value of $12.60 \mu \mathrm{g} / \mathrm{ml}$ in comparison with the positive control which showed moderate in vitro antimalarial activity with an $\mathrm{IC}_{50}$ value of $40.00 \mu \mathrm{g} / \mathrm{ml}$ according to inhibitory concentration values as described by Niharika et al. (2015). The isolated compound in this research has been shown to exhibit various biological and medicinal properties such as antimalarial, antibacterial, anthelminthic, anti-inflammatory and anticancer activities (Moghaddam and Kermani 2012).

The inhibitory concentration $\left(\mathrm{IC}_{50}\right)$ value of the isolated compound (betulinic acid) in this research indicates that the compound can serve as a viable drug lead in the treatment of malaria.

\section{Conclusion}

The phytochemical investigation of extracts obtained from the stem bark of Feretia canthioides Hiern in this research revealed the presence of vital plant secondary metabolites responsible for the therapeutic properties of medicinal plants. A known pharmacologically active triterpenoid, (betulinic acid) has been isolated and characterized for the first time from the stem bark of this plant. The antimalarial activity result of the isolated compound (betulinic acid) which was isolated from the methanolic extract of this plant has proved the potential of this plant in the treatment of malaria. The fact that 
Table $4{ }^{13} \mathrm{C}-\mathrm{NMR}$ (400 MHz, DMSO) data of isolated compound in comparison with literature data

\begin{tabular}{|c|c|c|c|}
\hline $\begin{array}{l}\text { Carbon } \\
\text { position }\end{array}$ & $\begin{array}{l}{ }^{13} \mathrm{C} \delta(\mathrm{ppm}) \text { (Mahato } \\
\text { and Kundu 1993) }\end{array}$ & $\begin{array}{l}{ }^{13} \mathrm{C} \delta(\mathrm{ppm}) \text { (Isolated } \\
\text { compound DZ1) }\end{array}$ & $\begin{array}{l}\text { Carbon } \\
\text { type }\end{array}$ \\
\hline$C-1$ & 38.70 & 39.43 & $\mathrm{CH}_{2}$ \\
\hline$C-2$ & 27.40 & 27.36 & $\mathrm{CH}_{2}$ \\
\hline$C-3$ & 78.90 & 77.04 & $\mathrm{CH}$ \\
\hline$C-4$ & 38.80 & 38.71 & C \\
\hline$C-5$ & 55.30 & 55.12 & $\mathrm{CH}$ \\
\hline$C-6$ & 18.30 & 18.17 & $\mathrm{CH}_{2}$ \\
\hline$C-7$ & 34.30 & 34.13 & $\mathrm{CH}_{2}$ \\
\hline$C-8$ & 40.70 & 39.97 & $C$ \\
\hline C-9 & 50.50 & 50.15 & $\mathrm{CH}$ \\
\hline$C-10$ & 37.20 & 36.93 & C \\
\hline$C-11$ & 20.80 & 20.67 & $\mathrm{CH}_{2}$ \\
\hline$C-12$ & 25.50 & 25.29 & $\mathrm{CH}_{2}$ \\
\hline$C-13$ & 38.80 & 37.78 & $\mathrm{CH}$ \\
\hline$C-14$ & 42.40 & 42.19 & C \\
\hline$C-15$ & 30.50 & 30.33 & $\mathrm{CH}_{2}$ \\
\hline$C-16$ & 32.10 & 31.93 & $\mathrm{CH}_{2}$ \\
\hline$C-17$ & 56.30 & 55.63 & $C$ \\
\hline$C-18$ & 46.80 & 46.84 & $\mathrm{CH}$ \\
\hline$C-19$ & 49.20 & 48.73 & $\mathrm{CH}$ \\
\hline$C-20$ & 29.70 & 29.43 & $\mathrm{CH}_{2}$ \\
\hline$C-21$ & 37.00 & 36.57 & $\mathrm{CH}_{2}$ \\
\hline$C-22$ & 150.30 & 150.52 & $C$ \\
\hline$C-23$ & 27.90 & 28.30 & $\mathrm{CH}_{3}$ \\
\hline$C-24$ & 15.30 & 15.94 & $\mathrm{CH}_{3}$ \\
\hline$C-25$ & 16.00 & 15.94 & $\mathrm{CH}_{3}$ \\
\hline$C-26$ & 16.10 & 16.09 & $\mathrm{CH}_{3}$ \\
\hline$C-27$ & 14.70 & 14.58 & $\mathrm{CH}_{3}$ \\
\hline$C-28$ & 180.50 & 177.49 & $\mathrm{COOH}$ \\
\hline$C-29$ & 109.60 & 109.82 & $\mathrm{CH}_{2}$ \\
\hline$C-30$ & 19.40 & 19.14 & $\mathrm{CH}_{3}$ \\
\hline
\end{tabular}

the stem bark of Feretia canthioides Hiern showed some level of antimalarial activity while screened in vitro for antimalarial activities in this research justifies its ethnopharmacological use for the traditional treatment of malaria.

\section{Abbreviations}

TLC: Thin layer chromatography; $R_{f}$ : Retention factor; RPMl: Roswell Park Memorial Institute; HEPES: (4-(2-hydroxyethyl)-1-piperazineethanesulfonic acid); WHO: World Health Organization; DMSO: Dimethyl sulfoxide; NMR: Nuclear magnetic resonance; FTIR: Fourier transform infrared spectroscopy

\section{Acknowledgements}

The authors would like to express their profound gratitude to Mr. Christian Oche of Chemistry Department, Ahmadu Bello University, Zaria, Kaduna State Nigeria for his assistance in the selection of this plant for research purposes as well as the Multi-User Laboratory, Ahmadu Bello University, Zaria, for making the laboratory available for the spectroscopic analysis.

\section{Authors' contributions}

Chiedozie O. Egbubine [COE] designed this research work and performed the experiments for extraction and isolation of the bioactive compound. The spectral analysis of the isolated compound was carried out by James $D$ Habila [JDH]. Modupe M Adeyemi [MMA] guided and supervised this research work along with JDH. All authors read and approved the final manuscript.

\section{Funding}

Not applicable.

\section{Availability of data and materials}

All data generated or analysed in this study are available from the corresponding authors on reasonable request.

\section{Ethics approval and consent to participate}

Ethical approval for the use of human tissue was obtained from the Health Research Ethics Committee of the Federal Ministry of Health and Human Services, Kaduna state with approval reference number MOH/ADM/744/ VOL.1/739.

\section{Consent for publication}

Not applicable.

\section{Competing interests}

The authors declare that they have no competing interests.

\section{Author details}

'Department of Chemistry, Nigerian Defence Academy (NDA), Kaduna State, Nigeria. ${ }^{2}$ Department of Chemistry, Ahmadu Bello University, Zaria, Kaduna State, Nigeria.

Received: 13 September 2019 Accepted: 18 March 2020

Published online: 06 April 2020

\section{References}

Azas N, Laurencin N, Delmas F, Di-Giorgio C, Gasquet M, Laget M, Timon-David P (2002) Synergistic in vitro antimalarial activity of plant extracts used as traditional herbal remedies in Mali. Parasitol Res 88:165-171

Dalziel JM, Hutchinson JM, Keay RW, Hepper FN (2014). All Territories in West Africa South of Latitude $18^{\circ} \mathrm{N}$ and to the West of Lake Chad and Fernando Po. J Flora West Afr 81:397-398

Devi AP, Fatria N, Widyawaruyanti ATY, Hafid AF, Tumewu L, Tantular IS (2014) In vitro antimalarial activity screening of several Indonesian plants using HRP2 assay. Int J Pharm Pharmaceutical Sci 6:125-128

Dubey KK, Goel N (2013) Evaluation and optimization of downstream process parameters for extraction of betulinic acid from the bark of Ziziphus jujubae L. ScientificWorldJournal:1-10. https://doi.org/10.1155/2013/469674

Etkin NL (2003) The co-evolution of people, plants and parasites: biological and cultural adaptions to malaria. Proc Nut Soc 62:311-317

Mahato SB, Kundu AP (1993) Triterpenoids and their glucosides from Terminalia chebula. Phytochemistry 32:999-1002

Moghaddam MG, Kermani AS, Ahmad FB (2012) Biological activity of betulinic acid: a review. Pharmacology Pharmacy 3:119-123 http//dx.doi.org/10.4236

Mustofa J, Sholikhah EN, Wahyuono S (2007) In vitro and in vivo antiplasmodial activity and cytotoxicity of extracts of Phyllanthus niruri L. herbs traditionally used to treat malaria in Indonesia. Southeast Asian J Trop Med Public Health 38(4):609-615

Niharika S, Kaushik NK, Dinesh M, Tiwari S, Sahal D (2015) Antiplasmodial activity of medicinal plants from Chhotanagpur plateau, Jharkhand, India. J Ethnopharmacol 165:152-162

Olasehinde G, Ojurongbe O, Adeyeba OA, Fagade O, Valecha N, Ayanda OI, Ajayi AA, Egwari OL (2014) In vitro studies on the sensitivity pattern of Plasmodium falciparum to anti-malarial drugs and local herbal extracts. Malaria J 13:63-64. https://doi.org/10.1186/1475-2875-13-63

Tanaka H, Sato M, Fujiwara S (2002) Antibacterial activity of isoflavonoids isolated from Erythrina variegata against methicillin resistant Staphylococcus aureus. Lett.Appl.Microbiol 35:228-489 
Trager W, Jensen JB (2005) Human malaria parasites in continuous culture. J Parasitol 91(3):484-486

WHO (2000) Expert committee on malaria, 20th report. World Health Organization technical report series, Geneva Document reference http:// www.who.int/iris/handle/10665/42247

Wright CW, Allen D, Cai Y, Chen ZP, Phillipson JD, Kirby GC, Warhurst DC, Tits M, Angelot L (1994) Selective antiprotozoal activity of some Strychnos alkaloids. Phytother Res 8:149-152

Zofou D, Tene M, Ngemenya MN, Tane P, Titanji VP (2011). In vitro antiplasmodial activity and cytotoxicity of extracts of selected medicinal plants used by traditional healers of Western Cameroon. J Malar Res Treat 2011: 1-6 https:// doi.org/10.4061/2011/561342

\section{Publisher's Note}

Springer Nature remains neutral with regard to jurisdictional claims in published maps and institutional affiliations.

\section{Submit your manuscript to a SpringerOpen ${ }^{\circ}$ journal and benefit from:}

- Convenient online submission

- Rigorous peer review

- Open access: articles freely available online

- High visibility within the field

- Retaining the copyright to your article

Submit your next manuscript at $\boldsymbol{\nabla}$ springeropen.com 